\title{
David Oliver: Falling immigration could destroy the NHS
}

\section{David Oliver consultant in geriatrics and acute general medicine}

Berkshire

Workforce gaps currently pose a major threat to the viability of our health services, as noted in a joint 2018 report by the King's Fund, Nuffield Trust, and Health Foundation.

One in 11 NHS clinical posts is currently unfilled, rising to one in eight nursing posts. ${ }^{2}$ The report estimates that, without concerted action, the current shortage of NHS staff employed by trusts in England—already around 100000 -will grow to an estimated 250000 by 2030 .

Some of the proposed solutions have been put forward before, by organisations including NHS Providers ${ }^{3}$ and the Royal College of Physicians. ${ }^{4}$ These centre on training more staff at home and doing more to look after staff so that more of them stay in the workforce. But this will take years, so let's get real.

\section{Burdensome process}

There is no magic workforce tree and, without workers from overseas, the NHS is on a slippery cliff edge. Around 144000 NHS staff (12.7\% of the total) have non-British nationality, and $63000(5.7 \%)$ have non-UK European Union nationality. ${ }^{5}$ These numbers are far higher in some specialties, organisations, and regions-often the least glamorous and the most in need.

But clinicians from overseas who want to work here are put off by the burdensome process of dealing with professional registration and regulation and by immigration bureaucracy. Tier 2 visa rules requiring new entrants to be earning or expecting to earn over $£ 30000$ ( $€ 33400 ; \$ 37$ 900) a year, even those from the EU, disqualify a range of nursing and allied health professional staff and junior doctors. ${ }^{6}$

There is no magic workforce tree and, without workers from overseas, the NHS is on a slippery cliff edge

Applying for visas carries costs for applicants and a further cost and administration burden for employers, estimated at $£ 490 \mathrm{~m}$ a year post-Brexit. ${ }^{7}$ Although the home secretary announced a relaxation in visa restrictions for doctors and nurses in 2018, ${ }^{8}$ he then said that this was temporary. ${ }^{9}$ December's immigration white paper discussed increasing the number of tier 2 visas-but not lowering the $£ 30000$ salary threshold that will exclude many skilled clinical staff. ${ }^{10}$ Are we actively trying to confuse or put off potential immigrant NHS workers?

Of course, the UK should not set out to strip poorer countries of clinicians they've trained, but schemes such as the Medical Training Initiative offer a win-win solution. This stipulates that non-EU doctors who come to the UK under the scheme must return home after 24 months, with the training and knowledge they've gained while working for the NHS. ${ }^{11}$ The scheme was capped at 1500 places a year but after concerted lobbying is set to increase to 3000 , bucking the bad news trend. ${ }^{12}$

\section{Net exit from the NHS}

Even though Brexit has yet to be implemented, the mood music and ongoing uncertainty mean that EU trained clinicians no longer feel welcome or certain of their future here. As a result, the number of EU nurses registering to practice here has fallen dramatically, ${ }^{13}$ and for the first time in over 20 years we have a net exit from the NHS by EU trained clinicians. ${ }^{14}$

Barnstorming rhetoric from pro-leave campaigners, newspapers, and MPs have made immigration a signal issue. Opinion polls have shown that immigration curbs and the need to control our own borders were key factors in the leave vote. ${ }^{15}$ In reality we've been able to control non-EU immigration for years and have expediently chosen not to-partly because public services such as the NHS need the staff.

Of course, we need to train more of our own staff and to do a much better job of retaining them. But policies and attitudes that adversely affect our current and potential immigrant workforce will sabotage our own interests and those of patients who might need the NHS.

Competing interests: See www.bmj.com/about-bmj/freelance-contributors/davidoliver

Provenance and peer review: Commissioned; not externally peer reviewed.

King's Fund, Nuffield Trust, Health Foundation. The health care workforce in England: make or break? 15 Nov 2018. https://www.kingsfund.org.uk/publications/health-careworkforce-england. 
2 Siddique H. NHS England has one in 11 posts unfilled. Guardian 21 Feb 2018. https:// www.theguardian.com/society/2018/feb/21/nhs-england-has-one-in-11-posts-unfilled.

3 NHS Providers. A better future for the NHS workforce. Nov 2017. https://nhsproviders. org/a-better-future-for-the-nhs-workforce.

4 Royal College of Physicians. RCP policy: workforce. 12 Oct 2015. https://www.rcplondon. ac.uk/projects/rcp-policy-workforce.

5 House of Commons Library. NHS staff from overseas: statistics. 10 Oct 2018. https:// researchbriefings.parliament.uk/ResearchBriefing/Summary/CBP-7783.

6 Swinford S. EU migrants will have to earn $£ 30000$ before coming to Britain under crackdown. 15 Dec 2018. https://www.telegraph.co.uk/politics/2018/12/14/eu-migrantswill-have-earn-30000-coming-britain-crackdown/.

7 Royal College of Physicians. The $£ 490$ million question: is this the new cost of overseas health workers post-Brexit? 5 Sept 2018. https://www.rcplondon.ac.uk/news/490-millionquestion-new-cost-overseas-health-workers-post-brexit.

8 NHS groups welcome immigration change for doctors and nurses. BBC News 14 June 2018. https://www.bbc.co.uk/news/uk-politics-44477095.

9 Grierson J, Campbell D. Easing of visa rules for doctors is temporary, says Sajid Javid. Guardian 11 Oct 2018. https://www.theguardian.com/uk-news/2018/oct/11/easing-of-visarules-for-doctors-is-temporary-says-sajid-javid.
10 Immigration: white paper sets out post-Brexit rules for migrants. BBC News 19 Dec 2018. https://www.bbc.co.uk/news/uk-politics-46613900.

11 Academy of Medical Royal Colleges. Medical Training Initiative. www.aomrc.org.uk medical-training-initiative/.

12 Campbell D. Government set to relax restrictions on non-EU doctors. Guardian 29 Nov 2018. https://www.theguardian.com/society/2018/nov/29/government-set-to-relaxrestrictions-on-non-eu-doctors.

13 Boffey D. Record numbers of EU nurses quit NHS. Guardian 18 March 2018. https://www. theguardian.com/society/2017/mar/18/nhs-eu-nurses-quit-record-numbers.

14 House of Commons Library. Effect on the NHS of the UK leaving the EU. Debate pack CDP 2018-0078. 21 March 2018. http://researchbriefings.files.parliament.uk/documents/ CDP-2018-0078/CDP-2018-0078.pdf

15 Centre for Social Investigation, Economic and Social Research Council. CSI Brexit 4: people's stated reasons for voting leave or remain. 24 April 2018. http://csi.nuff.ox.ac.uk/ wp-content/uploads/2018/05/Carl_Reasons_Voting.pdf.

Published by the BMJ Publishing Group Limited. For permission to use (where not already granted under a licence) please go to http://group.bmj.com/group/rights-licensing/ permissions 